\title{
KINERJA BIDANG MITIGASI BENCANA ALAM KABUPATEN SUBANG
}

\author{
Kusman Yuhana ${ }^{1}$ \\ Fakultas Ilmu Administrasi Universitas Subang \\ yuhanakusman.yk67@gmail.com
}

\section{Sumarna ${ }^{2}$}

Fakultas Ilmu Administrasi Universitas Subang

asepsumarna1968@gmail.com

\begin{abstract}
Abstrak
Tujuan penelitian ini adalah untuk mengetahui bagaimana kinerja bidang mitigasi bencana alam di badan penanggulangan bencana daerah melalui kegiatan observasi lapangan. Penelitian ini mengacu pada pendapat Agus Dwiyanto (1995:9) menjelaskan bahwa pada kinerja organisasi terfokus pada aspek produktifitas, kualitas pelayanan, responsivitas, responsibilitas, dan akuntabilitas. Metode penelitian yang digunakan adalah desriptif dengan pendekatan kualitatif. Penelitian diarahkan untuk membuat deskripsi, gambaran secara sistematis, faktual dan akurat mengenai fakta-fakta. Jenis data yang digunakan adalah data primer dan sekunder dengan instrument penelitian menggunakan pedoman wawancara sebagai penuntun bagi peneliti untuk mengembangkan pertanyaan. Hasil penelitian menunjukkan bahwa produktifitas yang berbicara tetang bagaimana pemberian pelayanan petugas kepada masyarakat, kualitas pelayanan berbicara pada kualitas sumber daya manusia yang dimiliki, responsivitas berbicara tentang kecepat tanggapan para petugas dalam pemberian pelayanan, responsibilitas berbicara tentang pertanggungjawaban individu dari petugas dan akuntablitas berbicara tentang pertanggungjawaban organisasi atau kelompok petugas. Pada intinya kinerja bidang mitigasi bencana alam di Badan Penanggulanga Bencana Daerah Kabupaten Subang belum optimal.
\end{abstract}

Kata Kunci: Kinerja organisasi, Bencana Alam

\section{Abstract}

The purpose of this study was to determine how the performance of the natural disaster mitigation field in the regional disaster management agency through field observation activities. This study refers to the opinion of Agus Dwiyanto (1995: 9) explaining that the organizational performance is focused on aspects of productivity, service quality, responsiveness, responsibility, and accountability. The research method used is descriptive qualitative approach. Research is directed to make a description, a systematic, factual and accurate description of the facts. The type of data used are primary and secondary data with research instruments using interview guidelines as a guide for researchers to develop questions. The results showed that productivity spoke about how the provision of service to 


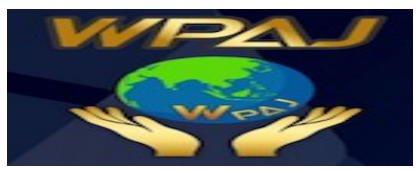

Volume 2 Issue 1, Juni 2020

http:// ejournal.unsub.ac.id/index.php/publik

officers to the community, quality of service spoke to the quality of human resources owned, responsiveness spoke of the speed of responses of officers in service delivery, responsibility spoke of individual accountability of officers and accountability spoke of organizational responsibility or group of officers. In essence, the performance of the field of natural disaster mitigation in the Subang District Disaster Management Agency is not yet optimal.

Keywords: Organizational performance, Natural Disasters

\section{Pendahuluan}

Bencana alam seperti gempa bumi, tsunami, banjir, longsor, letusan gunung api dan lain-lain. Wilayah Indonesia, merupakan Negara kepulauan yang terletak pada pertemuan tiga lempeng tektonik dunia yaitu: lempeng Hindia-Australia di sebelah selatan, lempeng Eurasia di sebelah barat dan lempeng Pasifik di sebelah timur (BNPB). Indonesia merupakan Negara yang memiliki tingkat kerawanan bencana alam tinggi, seperti letusan gunung merapi, gempa bumi, tsunami, banjir, tanah longsor, dan lain sebagainya. Tercatat setidaknya 3,397 kejadian bencana di Indonesia selama tahun 2018 (BNPB). Data Menunjukan bahwa Indonesia merupakan negara yang memiliki tingkat bencana alam yang cukup tinggi. (Sumber:data BNPB)

Berdasarkan Catatan Sejarah Jawa Barat Sudah Sering Mengalami Bancana Tanah Longsor Dan Banjir tercatat 1.936 kasus yang terjadi dalam kurun waktu 10 tahun terakhir. Namun Di Kabupaten Subang terdapat 192 selama tahun 2017 dengan kategori bencana alam banjir, longsor, angin puting beliung, pohon tumbang, dan kebakaran. Kabupaten Subang terbagi menjadi 3 bagian wilayah, yakni wilayah selatan, wilayah tengah dan wilayah utara. Bagian selatan wilayah Kabupaten Subang terdiri atas dataran tinggi/pegunungan, bagian tengah wilayah Kabupaten Subang berupa dataran, sedangkan bagian Utara merupakan dataran rendah yang mengarah langsung ke Laut Jawa. Sebagian besar wilayah Pada bagian selatan kabupaten Subang berupa Perkebunan, baik perkebunan Negara maupun perkebunan rakyat, hutan dan lokasi Pariwisata. Pada bagian tengah wilayah kabupaten Subang berkembang perkebunan karet, tebu dan buah-buahan dibidang pertanian dan pabrik-pabrik dibidang Industri, selain perumahan dan pusat pemerintahan serta instalasi militer. Kemudian pada bagian utara wilayah Kabupaten Subang berupa sawah berpengairan teknis dan tambak serta pantai. . (Sumber : data BPBD)

Tingkat kemiringan dan Iklim dilihat dari tingkat kemiringan lahan, sekitar $80.80 \%$ wilayah Kabupaten memiliki tingkat kemiringan $0^{\circ}-17^{\circ}, 10.64 \%$ dengan tingkat kemiringan $18^{\circ}-45^{\circ}$ sedangkan sisanya (8.56 \% memiliki kemiringan di atas $45^{\circ}$. Secara umum wilayah Kabupaten Subang beriklim tropis, dan curah hujan ratarata pertahun 3000-4000 mm dengan jumlah hari hujan 100 hari. Dengan iklim yang demikian, serta ditunjang oleh adanya lahan yang subur dan banyaknya aliran sungai, menjadikan sebagian besar luas tanah Kabupaten Subang digunakan untuk Pertanian. (Sumber : data BPS)

Mitigasi bencana adalah serangkaian upaya untuk mengurangi risiko bencana, baik melalui pembangunan fisik maupun penyadaran dan peningkatan kemampuan 


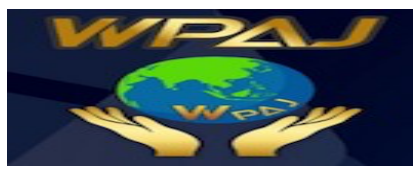

Volume 2 Issue 1, Juni 2020

http://ejournal.unsub.ac.id/index.php/publik

menghadapi ancaman bencana (Pasal 1 ayat 6 PP No 21 Tahun 2008 tentang Penyelenggaraan Penanggulangan Bencana). Mitigasi didefinisikan sebagai upaya yang ditujukan untuk mengurangi dampak dari bencana, Mitigasi adalah serangkaian upaya untuk mengurangi risiko bencana, baik melalui pembangunan fisik maupun penyadaran dan peningkatan kemampuan menghadapi ancaman bencana Peraturan Bupati Subang Nomor 71 Tahun 2016 tentang Tugas Pokok, Fungsi dan Tata Kerja Dinas Pemedam Kebakaran dan Penanggulangan Bencana Kabupaten Subang. (Sumber : data BPBD)

Badan Penanggulangan Bencana Daerah kabupaten subang merupakan salah satu organisasi yang mempunya tugas pokok dalam melaksanakan pennggulangan bencana dalam bidang mitigasi. Peran BPBD terutama dalam bidang mitigasi sangat penting untuk membantu masyarakat salam mencegah bencana alam. Berupa mengadakan kegiatan sosialisasi megenai pengenalam pencegahan bencana alam di siaga bencana di daerah setempat. Tujuan dilakukan sosialisasi merupakan salah satu wujud dari visi misi BDBP Kabupaten Subang dalam mewujudkan daerah yang masyarakat sigap dalam meakukan penaggulangan bencana alam. (Sumber : data BPBD)

Permasalahan di bidang mitigasi terlihat dari proses sosialisasi akan pentingnya pencegahan penanggulangan bencana kepada masyarakat masih belum terealisasikan dengan baik ini terlihat dari per 3 bulan sekali dilakukannya sosialisasi namun pada kenyataannya dalam 1 tahun hanya sekali dalam melakukan sosialisasi tersebut. Selain itu permasalahan lainnya terlihat dari masih belum tercukupi posko penanggulangan bencana ini terlihat dari baru terbangunnya posko tersebut $5 \%$ yang ada di kecamatan subang mengakibatkan proses pelaksanaan sosialisasi kepada masyarakat menjadi terhambat. (Sumber : data BPBD)

Keadaan tersebut masih harus diperbaiki dimulai dari penyampaian informasi tentang pentingnya pencegahan bencana alam yang merupakan wujud dari sosialisasi yang dilakukan BPBD terfokus pada bidang Mitigasi serta pengadaan posko penanggulangan bencana untuk mempermudah proses pelaksanaan sosialisasi tersebut. (Sumber :pribadi)

Berdasarkan hasil penelitian yang penulis lakukan, tentang Kinerja Bidang Mitigasi Bencana Alam di Kabupaten Subang terdapat indikator permasalahan sebagai berikut: Kemampuan organisasi perihal sumber daya manusia dinilai masih kurang ini dilihat dari ketersediaan tenaga ahli yang kurang cukup memadai yang harusnya 7 namun hanya ada 3. Kemudian ditemukan kurang tersedianya sarana dan prasarana sehingga kualitas pelayanan yang ada di Bidang Mitigasi Bencana Alam di Kabupaten Subang dinilai belum memadai.

\section{Kerangka Teori \\ Kinerja}

Menurut kamus besar bahasa indonesia, secara etimologis kinerja diartikan sebagai sesuatu yang dicapai atau prestasi yang diperlihatkan. Kinerja dalam pengertiannya dartikan sebagai prestasi yang diperlihatkan dalam kegiatan atau pekerjaan yang telah dilakukan.Sedangkan Mahsun (2006:25) kinerja adalah gambaran mengenai tingkatan pencapaian pelaksanaan suatu kegiatan / program / 


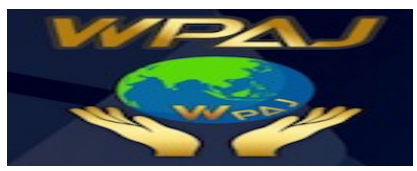

Volume 2 Issue 1, Juni 2020

http://ejournal.unsub.ac.id/index.php/publik

kebijakan dalam mewujudkan tujuan, misi, dan visi organisasi yang tertuang dalam strategic planning suatu organisasi. Sementara itu, menurut Sinambela (2014:140) mengemukakan bahwa kinerja merupakan implementasi dari teori keseimbangan, yang mengatakan bahwa seseorang akan menunjukan prestasi yang optimal bila ia mendapatkan manfaat (benefit) dan terdapat adanya rangsangan (inducement) dalam pekerjaannya secara adil dan masuk akal (reasonable). Menurut Mangkunegara (2006:9) mengemukakan kinerja (prestasi kerja) ialah hasil kerja secara kualitas dan kuantitas yang dicapai oleh seseorang pegawai dalam melaksanakan tugasnya sesuai dengan tanggungjawab yang diberikan kepadanya. Kinerja merupakan keluaran yang dihasilkan secara kualitas dan kuantitas. Pencapaian tersebut dihasilkan dari pegawai yang bertanggungjawab dengan pekerjaannya.

Menurut Keban (2003:43), menyebutkan bahwa kinerja (performance) dalam organisasi didefinisikan sebagai tingkat pencapaian hasil (the degree of accomplishment) atau kinerja merupakan tingkat pencapaian tujuan organisasi secara berkesinambungan. Selanjutnya, Steers (2003:67) mengemukakan bahwa kinerja organisasi adalah tingkat yang menunjukan seberapa jauh pelaksanaan tugas dapat dijalankan secara aktual dan misi organisasi tercapai. Sedangkan, Mahsun (2006:25) berpendapat bahwa kinerja adalah gambaran mengenai tingkat pencapaian pelaksanaan suatu kegiatan atau program dan kebijakan dalam mewujudkan sasaran, tujuan, visi dan misi organisasi yang tertuang dalam strategic planning suatu organisasi.

Menurut Mahmudi (2013:20) berpendapat bahwa kinerja merupakan suatu konstruk multidimensional yang mencakup banyak faktor yang mempengaruhinya, diantaranya yaitu:

1. Faktor personal/individu, meliputi: pengetahuan, keterampilan (skill), kemampuan, kepercayaan diri, motivasi, dan komitmen yang dimiliki oleh setiap individu;

2. Faktor kepemimpinan, meliputi: kualitas dalam memberikan dorongan, semangat, arahan, dan dukungan yang diberikan manajer dan team leader.

3. Faktor tim, meliputi: kualitas dukungan dan semangat yang diberikan oleh rekan dalam satu tim, kepercayaan terhadap sesama anggota tim, kekompakan dan keeratan anggota tim;

4. Faktor sistem, meliputi:sistem kerja, fasilitas kerja atau infrastruktur yang diberikan oleh organisasi, proses organisasi, dan kultur kinerja dalam organisasi;

5. Faktor kontekstual (situasional), meliputi: tekanan dan perubahan lingkungan eksternal dan internal.

Wibowo (2011:4), berpendapat bahwa kinerja adalah merupakan implementasi dari rencana yang telah disusun. Implementasi kinerja dilakukan oleh sumber daya manusia yang memiliki kemampuan, kompetensi, motivasi, dan kepentingan. Bagaimana organisasi menghargai dan memperlakukan sumber daya manusianya akan mempengaruhi sikap dan prilakunya dalam menjalankan kinerja. Sejalan dengan apa yang dikemukakan oleh Hersey dan Blanchard (1993), bahwa kinerja merupakan suatu fungsi dari motivasi dan kemampuan untuk menyelesaikan tugas atau pekerjaan. Seseorang harus memiliki derajat kesediaan dan tingkat kemampuan tertentu. Kesediaan dan keterampilan seseorang tidaklah cukup efektif untuk 


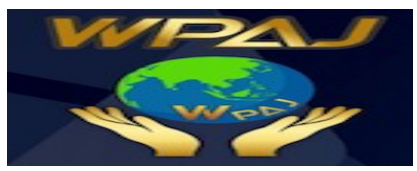

Volume 2 Issue 1, Juni 2020

http://ejournal.unsub.ac.id/index.php/publik

mengerjakan sesuatu tanpa pemahaman yang jelas tentang apa yang dikerjakan dan bagaimana mengerjakannya.

Lain hal menurut Prawirosentono (1999:2), kinerja adalah hasil kerja yang dapat dicapai oleh pegawai atau sekelompok pegawai dalam suatu organisasi, sesuai dengan wewenang dan tanggung jawab masing-masing,dalam upaya mencapai tujuan organisasi bersangkutan secara legal, tidak melanggar hukum dan sesuai dengan moral dan etika.

Agus Dwiyanto (1995: 9) mengemukakan beberapa indikator yang dapat digunakan dalam mengukur kinerja birokrasi publik, yaitu :

1. Produktivitas

Konsep produktivitas tidak hanya mengukur tingkat efisiensi, tetapi juga efektivitas pelayanan. Produktivitas pada umumnya dipahami sebagai rasio antara input dengan output. Pada tataran ini, konsep produktivitas dirasa terlalu sempit sehingga General Accounting Office(GAO) mencoba mengembangkan satu ukuran produktivitas yang lebih luas dengan memasukkan seberapa besar pelayanan publik itu memiliki hasil yang diharapkan sebagai salah satu indikator kinerja yang penting.

2. Kualitas Layanan.

Isu mengenai kualitas layanan cenderung menjadi semakin penting dalam menjelaskan kinerja organisasi publik. Banyak pandangan negative mengenai organisasi publik muncul karena ketidakpuasan masyarakat terhadap kualitas layanan yang diterima dari organisasi publik. Dengan demikian, kepuasan masyarakat terhadap layanan dapat dijadikan indikator kinerja organisasi publik, sebab akses untuk mendapatkan informasi mengenai kualitas layanan relative sangat mudah dan murah.

3. Responsivitas.

Responsivitas adalah kemampuan organisasi untuk mengenali kebutuhan masyarakat, menyusun agenda dan prioritas pelayanan serta mengembangkan program-program pelayanan publik sesuai dengan kebutuhan dan aspirasi masyarakat. Dalam konteks ini, responsivitas mengacu pada keselarasan antara program dan kegiatan pelayanan dengan kebutuhan dan aspirasi masyarakat. Responsivitas dimasukkan sebagai salah satu indikator kinerja karena responsivitas secara langsung menggambarkan kemampuan organisasi publik dalam menjalankan misi dan tujuannya, terutama untuk memenuhi kebutuhan masyarakat. Responsivitas yang rendah ditunjukkan dengan ketidak selarasan antara pelayanan dengan kebutuhan masyarakat yang secara otomatis kinerja organisasi tersebut jelek. Hal tersebut jelas menunjukkan kegagalan organisasi dalam mewujudkan misi dan tujuan organisasi.

4. Responsibilitas.

Responsibilitas menjelaskan apakah pelaksanaan kegiatan organisasi publik itu dilakukan sesuai dengan prinsip-prinsip administrasi yang benar atau sesuai dengan kebijakan organisasi, baik yang eksplisit maupun implisit (Lenvine, 1990). Oleh sebab itu, responsibilitas bisa saja pada suatu ketika berbenturan dengan responsivitas.

5. Akuntabilitas. 


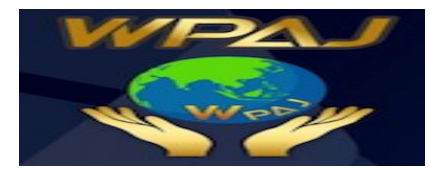

Volume 2 Issue 1, Juni 2020

http://ejournal.unsub.ac.id/index.php/publik

Akuntabilitas publik menunjuk pada seberapa besar kebijakan dan kegiatan organisasi publik tunduk pada para pejabat politik yang dipilih oleh rakyat. Asumsinya adalah bahwa para pejabat politik tersebut dipilih oleh rakyat, sehingga dengan sendirinya akan selalu merepresentasikan kepentingan rakyat. Dalam konteks ini, konsep akuntabilitas publik dapat digunakan untuk melihat seberapa besar kebijakan dan kegiatan organisasi publik itu konsisten dengan kehendak masyarakat banyak. Kinerja organisasi publik tidak hanya bisa dilihat dari ukuran internal yang dikembangkan oleh organisasi publik atau pemerintah, seperti pencapaian target, akan tetapi kinerja sebaiknya harus dinilai dari ukuran eksternal, seperti nilai-nilai dan norma yang berlaku dalam masyarakat. Suatu kegiatan organisasi publik memiliki akuntabilitas yang tinggi kalau kegiatan itu dianggap benar dan sesuai dengan nilai dan norma yang berkembang dalam masyarakat.

Menurut Hersey, Blanchard dan Johnson yang dikutip oleh Wibowo (2011:102) terdapat tujuh indikator kinerja yaitu:

1. Tujuan, merupakan keadaan yang berbeda yang secara aktif dicari oleh seorang individu dan organisasi untuk dicapai. Untuk mencapai tujuan diperlukan kinerja individu, kelompok, dan organisasi. Kinerja individu maupun organisasi berhasil apabila dapat mencapai tujuan yang diinginkan.

2. Standar, merupakan suatu ukuran apakah tujuan yang diinginkan dapat dicapai. Tanpa standar, tidak dapat diketahui kapan suatu tujuan tercapai. Kinerja seseorang dikatakan berhasil apabila mampu memcapai standar yang ditentukan atau disepakati bersama antara atasan dan bawahan.

3. Alat atau sarana, merupakan sumber daya yang dapat dipergunakan untuk membantu menyelesaikan tujuan dengan sukses. Alat atau saran merupakan faktor penunjang untuk mencapai tujuan.Tanpa alat atau sarana, tugas pekerjaan spesifik tidak dapat dilakukan dan tujuan tidak dapat diselesaikan sebagaimana seharusnya. Tanpa alat atau sarana tidak mungkin dapat melakukan pekerjaan.

4. Kompetensi, merupakan persyaratan utama dalam kinerja. Kompetensi merupakan kemampuan yang dimiliki oleh seseorang untuk menjalankan pekerjaan yang diberikan kepadanya dengan baik. Kompetensi memungkinkan seseorang mewujudkan tugas yang berkaitan dengan pekerjaan yang diperlukan untuk mencapai tujuan.

5. Motif, merupakan alasan atau pendorong bagi seseorang untuk melakukan sesuatu. Manajer memfasilitasi motivasi kepada karyawan dengan insentif berupa uang, memberikan pengakuan, menetapkan tujuan menantang, menetapkan standar terjangkau, meminta umpan balik, memberikan kebebasan melakukan pekerjaan termasuk waktu melakukan pekerjaan, menyediakan sumber daya yang diperlukan dan menghapuskan yang mengakibatkan disinsentif.

6. Peluang, pekerja perlu mendapatkan kesempatan untuk menunjukan prestasi kerjanya. Terdapat dua faktor yang menyumbangkan pada adanya kekurangan kesempatan untuk berprestasi, yaitu ketersediaan waktu dan kemampuan untuk memenuhi syarat. Jika pekerja dihindari karena supervisor tidak percaya terhadap kualitas dan kepuasan konsumen, mereka secara efektif akan dihambat dari kemampuan memenuhi syarat untuk berprestasi. 


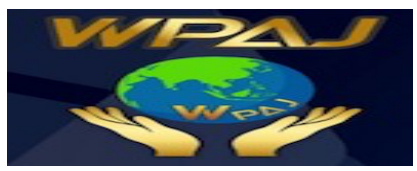

Volume 2 Issue 1, Juni 2020

http://ejournal.unsub.ac.id/index.php/publik

7. Umpan balik, antar tujuan, standar dan umpan balik bersifat saling terkait. Umpan balik melaporkan kemajuan, baik kualitas maupun kuantitas, dalam mencapai tujuan yang didefinisikan oleh standar. Umpan balik merupakan masukan yang dipergunakan untuk mengukur kemajuan kinerja, standar kinerja, dan pencapaian tujuan. Dengan umpan balik dilakukan evalusasi terhadap kinerja dan sebagai hasilnya dapat dilakukan perbaikan kinerja.

Sedangkan Moeheriono (2010:82), indikator kinerja dalam Akuntabilitas Kinerja Instansi Pemerintah (AKIP) disajikan sebagai berikut:

1. Masukan (inputs), yaitu ukuran tingkat pengaruh sosial ekonomi, lingkungan atau kepentingan umum lainnya yang dimulai oleh capaian indikator kinerja dalam suatu kegiatan.

2. Keluaran (outputs), kegunaan suatu keluaran (outputs) yang dirasakan langsung oleh masyarakat. Dapat berupa tersedianya fasilitas yang dapat diakses atau dinikmati oleh publik.

3. Hasil (outcomes), yaitu segala sesuatu yang mencerminkan berfungsinya keluaran kegiatan pada jangka menengah outcomes merupakan ukuran seberapa jauh setiap produk atau jasa dapat memenuhi kebutuhan dan harapan masyarakat.

4. Manfaat (benefits), yaitu segala sesuatu berupa produk/jasa (fisik dan nonfisik) sebagai hasil langsung dari pelaksanaan suatu kegiatan dan rogram berdasarkan masukan yang digunakan. Dampak (impacts), yaitu segala sesuatu yang dibutuhkan agar pelaksanaan kegiatan dan program dapat berjalan atau dalam rangka menghasilkan output, misalnya sumber daya manusia, dana, material, waktu, dan teknologi.

Sementara itu, Zeithaml, Parasuraman \& Berry yang dikutip oleh Ratminto \& Atik Septi Winarsih (2010:175) mengemukakan indikator kinerja pelayanan sebagai berikut:

1. Tangibles atau ketampakan fisik, artinya petampakan fisik dari gedung, peralatan, pegawai, dan fasilitas-fasilitas lain yang dimiliki oleh providers.

2. Reliability atau reliabilitas adalah kemampuan untuk menyelenggarakan pelayanan yang dijanjikan secara akurat.

3. Responsiveness atau responsivitas adalah kerelaan untuk menolong customers dan menyelenggarakan pelayanan secara ikhlas.

4. Assurance atau kepastian adalah pengetahuan dan kesopanan para pekerja dan kemampuan mereka dalam memberikan kepercayaan kepada customers.

5. Empathy adalah perlakuan atau perhatian pribadi yang diberikan oleh providers kepada customers.

Dalam organisasi birokrasi atau sektor publik, pendekatan manajemen yang sering digunakan adalah model pengendalian formal.Menurut Mahmudi (2013:58), pengendalian formal dilakukan melalui kegiatan-kegiatan resmi organisasi yang biasanya bersifat rutin, misalnya perencanaan strategik, pembuatan program,penganggaran, evaluasi kinerja, rapat atau pertemuan rutin, dan sebagainya.

Taylor yang dikutip oleh Mahmudi (2013:59) menyatakan bahwa pengendalian merupakan bentuk ilmiah dari manajemen. Sebelumnya manajemen dipahami sebagai seni semata-mata. Namun ternyata manajemen bisa dipelajari melalui pendekatan ilmiah. Pengendalian manajemen melalui beberapa aktivitas, yaitu: 
1. Perencanaan aktivitas yang akan dilakukan organisasi

2. Pengkoordinasian aktivitas berbagai bagian organisasi

3. Pengkomunikasian informasi ke seluruh bagian organisasi

4. Evaluasi terhadap informasi

5. Pembuatan keputusan

6. Mempengaruhi orang-orang dalam organisasi untuk mengubah prilaku

\section{Metode Penelitian}

Dalam penelitian penulis menggunakan metode deskriptif dengan pendekatan kualitatif. Artinya data yang dikumpulkan bukan berupa angka-angka, melainkan data tersebut berasal dari naskah wawancara, catatan lapangan, dokumen pribadi, memo dan dokumen resmi lainnya. Sehingga yang menjadi tujuan kualitatif ini adalah ingin menggambarkan realita empirik di balik fenomena secara mendalam, rinci dan tuntas. Oleh karena itu penggunaan pendekatan kualitatif dalam penelitian ini adalah dengan mencocokan antara realita empirik dengan teori yang berlaku dengan menggunakan metode deskriptif (Moleong, 2010:131).

Menurut Nazir (2009:54) bahwa metode deskriptif adalah suatu metode dalam penelitian status sekelompok manusia, suatu objek, suatu set kondisi, suatu sistem pemikiran, ataupun suatu kelas peristiwa pada masa sekarang. Tujuan dari penelitian deskriptif ini adalah untuk membuat deskripsi, gambaran atau lukisan secara sistematis, faktual dan fakta mengenai fakta-fakta, sifat serta hubungan antar fenomena yang diselidiki.

Metode ini dipakai untuk mengungkapkan secara komprehensif dan mendalami bagaimana perencanaan kebutuhan dan penyediaan tenaga kerja di Dinas Tenaga Kerja dan Transmigrasi Kabupaten Subang. Metode ini penelitiankualitatif lebih berdasarkan pada filsafat fenomenologis yang mengutamakan penghayatan dan berusaha untuk memahami serta menafsirkan makna suatu peristiwa interaksi tingkah laku manusia dalam situasi tertentu menurut perspektif peneliti sendiri.

\section{Hasil dan Pembahasan}

Sebagaimana yang telah dijelaskan pada Peraturan Bupati Subang Nomor 72 Tahun 2018 Tentang Tugas Pokok, Fungsi dan Tata Kerja Badan Penanggulangan Bencana Daerah Kabupaten Subang maka penelitian ini dilaksanakan untuk mengkaji tentang bagaimana Kinerja Bidang Mitigasi Bencana Alam di Badan Penanggulangan Bencana Daerah Kabupaten Subang. Namun pada kenyataannya di Kabupaten Subang belum menunjukan hasil yang signifikan dalam penanggulangan bencana alam yang terjadi maka sebagai tindak lanjut dari hasil penelaahan kondisi tersebut di atas, maka penulis mencoba memberikan pertanyaan yang lebih mendalam dikaitkan dengan Kinerja Organisasi yang dikemukakan oleh Menurut Agus Dwiyanto (1995:9) yang terdiri dari dimensi produktivitas, kualitas pelayanan, responsivitas, responsibilitas, dan akuntabilitas. 


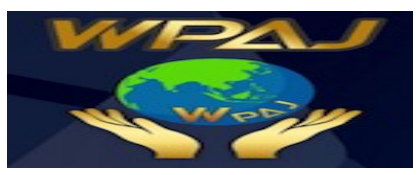

Volume 2 Issue 1, Juni 2020

http://ejournal.unsub.ac.id/index.php/publik

\section{Produktivitas}

Konsep produktivitas tidak hanya mengukur tingkat efisiensi, tetapi juga efektivitas pelayanan. Produktivitas pada umumnya dipahami sebagai rasio antara input dengan output. Pada tataran ini, konsep produktivitas dirasa terlalu sempit sehingga General Accounting Office (GAO) mencoba mengembangkan satu ukuran produktivitas yang lebih luas dengan memasukkan seberapa besar pelayanan publik itu memiliki hasil yang diharapkan sebagai salah satu indikator kinerja yang penting. Dalam konsep ini juga membahas tentang sarana dan prasarana yang dibutuhkan organisasi untuk menunjang keberhasilan suatu organisasai dalam mencapai tujuannya. Peneliti melakukan wawancara dengan informan 1 adalah Kepala Bidang Mitigasi Kabupaten Subang, bahwa : "Perihal produktivitas kerja bidang mitigasi sendiri mungkin mencakup tentang kegiatan-kegiatan yang kami lakukan dan berbicara tentang kegiatan tersebut diantaranya kami melakukan penyuluhan berupa sosialisasi pencegahan dan penanggulangan bencana agar masyarakat tau cara mengatasi, mencegah bencana saat pra bencana dan pasca bencana. Masalah yang terjadi terakait penyuluhan itu sendiri masyarakat kurang koperatif dalam menanggapi penyuluhan tentang mitigasi bencana. Namun tidak hanya itu saja yang menjadi kedala kami, salah satu kendalanya adalah sarana dan prasarana berupa alat dan dari pihak yang akan diberikan penyuluhan untuk membantu keberlangsungan proses sosialiasi ini". (Hasil Wawancara, 15 November 2019)

Berdasarkan Hasil keterangan wawancara dengan Kepala Bidang Mitigasi Kabupaten Subang dapat digambarkan bahwa upaya yang dilakukan oleh pihak BPBD dalam kegiatan penanggulangan bencanaadalah dengan melakukan sosialisasi maupun penyuluhan yang dilakukan terhadap masyarakat, namun pada kenyataanya banyak kendala yng dihadapi seperti masyarakat yang kurang merespon akan kegiatan ini dan masalah sarana dan prasarana yang kurang mendukung akan kegiatan ini.Peneliti juga melakukan wawancara dengan informan 2 adalah bagian Staff Mitigasi Kabupaten Subang, bahwa : Dalam kegiatan mungkin kami melakukan sosialisasi atau punyuluhan baik secara langsung ditempat yang telah dipilih maupun melalui media social agar masyarakat mengenal dan mengetahui apa yang harus dilakukan untuk mencegah sebelum bencana terjadi dan menanggulangi setelah bencana tersebut terjadi. Namun memang kami perlu alat untuk mempermudah kami dalam sosialisasi dan simulasi serta untuk melakukan observasi daerah rawan bencana, hanya saja keadaan alat yang terbatas menjadi kendala yang patut kami garis bawahi". (Hasil Wawancara, 17 November 2019) Berdasarkan uraian di atas diketahui bahwa Peran Bidang Mitigasi dalam pencegahan dan penaggulangan bencana sangat penting untuk masyarakat apalagi di daerah yang rawan bencana. Kegiatan sosialisasi dan penyuluhan juga sebagai simulasi akan cara yang harus dilakukan pada saat sebelum dan sesudah kejadian bencana. Dengan keterbatasan dan kurang memadainya sarana dan prasarana berupa alat untuk membantu masyarakat dalam memahami dan mencerna proses sosialisasi tersebut ini juga merupakan faktor yang menjadi penghambat.

Berdasarkan hasil wawancara dan observasi peneliti bahwa produktivitas bidang mitigasi dalam proses kegiatan sosialisasi dan penyuluhan apabila permasalahan tersebut dikaitkan dengan teori yang dikemukakan oleh Agus Dwiyanto (1995:9), bahwa konsep produktivitas bidang mitigasi dalam kegiatan 


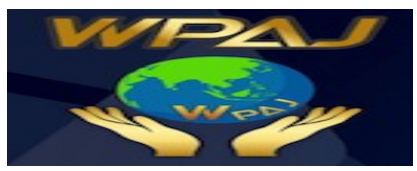

Volume 2 Issue 1, Juni 2020

http://ejournal.unsub.ac.id/index.php/publik

penyuluhan dan sosialiasi belum berjalan secara optimal sehingga belum mencapai hasil yang diharapkan.

Dapat disimpulkan bahwa dalam produktivitas kinerja bidang mitigasi untuk kegiatan sosialisasi dan penyuluhan di sini masih perlu ditingkatkan lagi dari segi sarana dan prasarana sebab sarana dan prasarana di sini berperan penting untuk simulasi dan pemahaman masyarakat dengan peragaan yang dilakukan.

\section{Kualitas Pelayanan}

Isu mengenai kualitas layanan cenderung menjadi semakin penting dalam menjelaskan kinerja organisasi publik. Banyak pandangan negatif mengenai organisasi publik muncul karena ketidakpuasan masyarakat terhadap kualitas layanan yang diterima dari organisasi publik. Dengan demikian, kepuasan masyarakat terhadap layanan dapat dijadikan indikator kinerja organisasi publik, sebab akses untuk mendapatkan informasi mengenai kualitas layanan relatif sangat mudah dan murah. mKualitas pelayanan disini menyangkut pada kesulitan mengakses informasi masyarakat karena terbatasnya sarana komunikasi yang ada di mayarakat desa terpencil karena memang pada umumnya masyarakat disana tidak terlalu mementingkan alat komunikasi namun ada sebagian massyarakat yang memiliki alat komunikasi namun mereka tidak mengetahui call center posko siaga bencana ini yang menyebabkan masyarakat sulit menghubungi dan bidang mitigasi sulit untuk sampai kelokasi karena keterbatasan saranan alat GPS.

Pada temuan di lapangan berkaitan dengan kualitas pelayanan, peneliti mewawancarai informan 1 adalah Kepala Bidang Mitigasi Kabupaten Subang dan Beliau menyebutkan bahwa: "Mengenai pemberian layanan ini juga kami lakukan dalam kegitan sosialisasi dan penyuluhan untuk pemberitahuan call center dan website dalam penyampaian informasi kegiatan yang kami lakukan namun memang pada kenyataan nya masih sedikit masyarakat yang paham dalam mengakses informasi tersebut, karena kerjasama antara kita dan masyarakat sangat diperlukan dalam mitigasi ini ". (Hasil Wawancara, 15 November 2019)

Berdasarkan Hasil keterangan wawancara dengan Kepala Bidang Mitigasi Kabupaten Subang mengenai kualitas layanan yang diberikan, dapat digambarkan bahwa kualitas layanan itu dilakukan pada saat kegiatan sosialisasi, yang dimana pihak BPBD memberikan nomor Call center kepada masyarakat dan memberikan pemahaman bahwa fungsi Call center itu sebagai nomor darurat yang harus dihubungi oleh masyarakat ketika ada bencana terjadi. Selanjutnya peneliti mewawancarai informan 2 adalah Pegawai BPBD Kab.Subang sebagai berikut : "Dalam pemberian pelayanan yang kami berikan hal yang menjadi masalah dalam msayarakat mungkin saja kurang pahamnya masyarakat dalam mengakses informasi berserta call center yang kami berikan, dari pihak kami juga masih kurang memadainya sarana dan prasarana yang kami miliki contohnya alat GPS untuk menjangkau lokasi yang akan kami observasi serta memberikan penyuluhan kepada warga yang ada disana". (Hasil Wawancara, 17 November 2019)

Berdasarkan Hasil keterangan wawancara dengan Pegawai BPBD Kab.Subang mengenai kualitas layanan yang diberikan, dapat digambarkan bahwa ada banyak kendala yang dimiliki oleh pihak BPBD tepatnya pada aduan maupun laporan masyarakat yang lokasi bencananya jangkaunya jauh dari kota sehingga pihak BPBD 


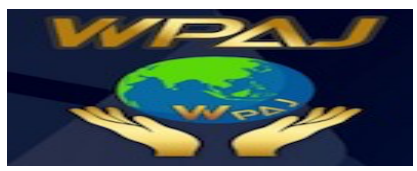

Volume 2 Issue 1, Juni 2020

http://ejournal.unsub.ac.id/index.php/publik

susah untuk mendeteksi lokasi terjadinya bencana, hal ini dikarenakan sarana dan prasarana dalam bentuk GPS masih belum canggih dan jangkauanya dinilai masih kurang menjangkau area-area yang jauh dari perkotaan.Kemudian peneliti mewanacarai informan 3 adalah pegawai BPBD Kab.Subang, sebagai berikut : "Kalau mengenai pemberian pelayanan saya beserta rekan-rekan sudah memberikan semaksimal mungkin baik itu pra bencana maupun pasca bencana. Namun terkadang masyarakat masih saja mengeluh akan kinerja kami, hal yang wajar karena kami masih kekurangan dalam sumber daya manusia nya sendiri, maka kami berusaha melakukan yang terbaik kedepan nya dalam melakukan pelayanan kepada masyarakat.". (Hasil wawancara 17 November 2019)

Berdasarkan Hasil keterangan wawancara dengan informan Pegawai BPBD lainya mengenai kualitas layanan yang diberikan, dapat digambarkan bahwa kurangnya pemahaman masyarakat mengenai sosialisasi yang diberikan oleh pihak BPBD diakibatkan karena kurangnya sumberdaya manusia yang tersedia di BPBD Kab. Subang yang mengakibatkan kurang meratanya sosialisasi yang dilakukan terhadap masyarakat.Hal tersebut juga dipertegas oleh informan 4 adalah masyarakat selaku pelaku yang merasakan pelaksanaan terkait dengan penyuluhan sebagai berikut: "Kalau kualitas pelayanan saya sendiri cukup paham dalam mengakses informasi ke call center yang disediakan. Saya akan hubungi ketika memang terjadi bencana di desa kami, namun sayang sekali website dari BPBD subang masih belum mengudara padahal hal itu sangat penting karena masyarakat ingin mengetahui data bencana di kabupaten subang". (Hasil wawancara 18 November 2019)

Dari hasil wawancara dengan beberapa informan dapat disimpulkan bahwa kualitas layanan yang di berikan Bidang Mitigasi sudah sesuai untuk kegiatan sosialisasi yang di lakukan sebagai mana itu menjadi edukasi untuk masyarakat dalam pencegahan dan penanggulangan bencana alam yang terjadi di daerah rawan bencana karena Bidang Mitigasi sendiri lebih memfokuskan melakukan kegiatan penyuluhan atau sosisalisasi pada daerah rawan bencana. Apabila permasalahan tersebut dikaitkan dengan teori yang dikemukakan oleh Agus Dwiyanto (1995:9), dalam indikator kualitas pelayanan masih belum optimal dalam hal penyampaian informasi dan cara pengaksesan informasi bagi masyarakat belum tersampaikan dengan baik ini karena terbatasnya pengetahuan masyarakat dan ketidak jelasan informasi yang mereka terima dari pihak Bidang Mitigasi.

\section{Responsivitas}

Responsivitas adalah kemampuan organisasi untuk mengenali kebutuhan masyarakat, menyusun agenda dan prioritas pelayanan serta mengembangkan program-program pelayanan publik sesuai dengan kebutuhan dan aspirasi masyarakat. Dalam konteks ini, responsivitas mengacu pada keselarasan antara program dan kegiatan pelayanan dengan kebutuhan dan aspirasi masyarakat. Responsivitas dimasukkan sebagai salah satu indikator kinerja karena responsivitas secara langsung menggambarkan kemampuan organisasi publik dalam menjalankan misi dan tujuannya, terutama untuk memenuhi kebutuhan masyarakat. Responsivitas yang rendah ditunjukkan dengan ketidak selarasan antara pelayanan dengan kebutuhan masyarakat yang secara otomatis kinerja organisasi 


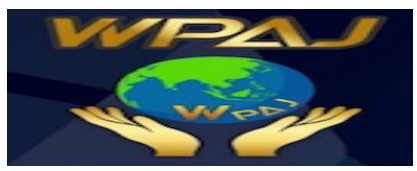

Volume 2 Issue 1, Juni 2020

http://ejournal.unsub.ac.id/index.php/publik

tersebut jelek. Hal tersebut jelas menunjukkan kegagalan organisasi dalam mewujudkan misi dan tujuan organisasi.

Dalam pengembangan program yang dilakukan Bidang Mitigasi lebih memprioritaskan kebutuhan masyarakat pada daerah rawan bencana dengan lebih menekankan pada penyuluhan paska bencana agar masyarakat lebih memahami cara penanggulangan bencana alam, peneliti melakukan wawancara dengan informan 1 adalah Kepala Bidang Mitigasi Kabupaten Subang, beliau mengatakan : "Perihal pentingnya penanggulangan bencana alam yang terjadi, kami pihak bidang mitigasi lebih memprioritaskan daerah-daerah rawan bencana mengapa, karena daerah tersebut perlu kami fokuskan agar masyarakat bisa mengetahui cara pencegahan dan penanggulanan bencana tersebut perlu diketahui bahwa kam sudah mempetakan daerah rawan bencana di kabupaten subang". (Hasil Wawancara, 15 November 2019) Berdasarkan Hasil keterangan wawancara dengan Kepala Bidang Mitigasi Kabupaten Subang mengenai responsivitas, dapat digambarkan bahwa pihak BPBD telah memprioritaskan sasaran utama dalam hal pelaksanaan kegiatan sosialisasi, sasaran utama yang dimaksud adalah masyarakat yang tinggal di area yang disenyalir rawan akan bencana alam. Lokasi rawan bencana itu dapat di klasifikasikan sepeti lokasi rawan longsor, banjir bandang dan lain-lain. Selanjutnya peneliti mewawancarai informan 2 adalah Pegawai BPBD Kab.Subang sebagai berikut: "Mengenai cepat tanggap terhadap pentingnya penanggulangan bencana kami lebih mengacu pada program yang kami buat dengan lebih mementingkan masyarakat yang berada di daerah rawan bencana tetapi juga kami melakukan sosialisasi pada masyarakat lain yang tidak berada di daerah rawan bencana agar mendapatkan edukasi yang sama agar lebih siaga terhadap kondisi alam yang terjadi". (Hasil Wawancara, 17 November 2019)

Berdasarkan Hasil keterangan wawancara dengan salah satu Pegawai BPBD Kab.Subang mengenai responsivitas, dapat digambarkan bahwa pihak BPBD tidak hanya memberikan pemahaman sosialisasi enanggulangan bencana kepada masyarakat yang lokasinya rawan bencana saja, namun sosialisasi juga dilakukan kepada masyarakat yang tinggal di tempat yang tidak rawan bencana juga dilakukan, hal itu dilakukan agar semua masyarakat memiliki ilmu dan wawasan mengenai penanggulangan bencana bilamana bencana itu terjadi.

Berdasarkan hasil wawancara yang dilakukan peneliti dengan beberapa informan dapat disimpulkan bahwa Apabila permasalahan tersebut dikaitkan dengan teori yang dikemukakan oleh Agus Dwiyanto (1995:9) dalam konsep responsivitas ketanggapan Bidang Mitigasi terhadap pencegahan dan penanggulangan bencana mereka melakukan penyusunan program yang lebih mementingkan masyarakat yang tinggal di daerah rawan bencana agar mereka lebih bisa memahami cara pencegahan dan penanggulangan bencana. Maka dari itu peran Bidang Mitigasi sangat penting untuk masyarakat sebagai pemberi edukasi perihal pentingnya pencegahan dan penanggulagan bencana alam.

\section{Responsibilitas}

Responsibilitas menjelaskan apakah pelaksanaan kegiatan organisasi publik itu dilakukan sesuai dengan prinsip-prinsip administrasi yang benar atau sesuai dengan kebijakan organisasi, baik yang eksplisit maupun implisit (Lenvine, 1990). 


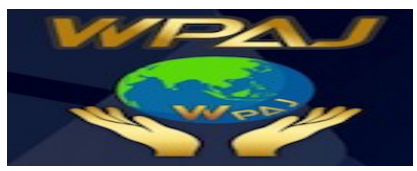

Volume 2 Issue 1, Juni 2020

http://ejournal.unsub.ac.id/index.php/publik

Oleh sebab itu, responsibilitas bisa saja pada suatu ketika berbenturan dengan responsivitas. Kegiatan organisasi pada Bidang Mitigasi dalam pelaksanaannya sudah sesuai dengan prinsip administrasi. Responsibilitas ini lebih berorientasi kepada tugas dimana yang memiliki kewajiban berhak untuk melakukan apapun untk menyelesaikan tugas yang di berikan ini juga merupakan tanggungjawab kelompok dalam penyelesaian kegiatan yang dilakukan. Peneliti melakukan wawancara dengan informan 1 adalah Kepala Bidang Mitigasi Kabupaten Subang, beliau mengatakan : "Perihal pengontrolan yang kami lakukan atas kinerja pegawai di lapangan biasanya kami mengadakan agenda rapat evaluasi per 3 bulan sekali untuk mengetahui sejauh mana keberhasilan program yang kami laksanakan dan bagaimana kerja para petugas di lapangan. Perihal pengetahuan petugas terhadap pekerjaanya sudah sesuai dengan bidang yang mereka kuasai namun yang menjadi masalah sumber daya manusia nya masih terbatas". (Hasil Wawancara, 15 November 2019)

Berdasarkan Hasil keterangan wawancara dengan Kepala Bidang Mitigasi Kabupaten Subang mengenai responsibilitas, dapat digambarkan bahwa ada fungsi pengawasan atau controlling yang dilakukan oleh Kepala Bidang Mitigasi Kabupaten Subang, yaitu dengan mengadakan rapat evaluai pegawai yang dilakukan setiap 3 bulan sekali, hal ini dilakukan untuk meningkatkan kinerja pegawai dan untuk mengetahui sejauh mana keberhasilan pegawai dalam pelaksanaan program yang dilaksanakan. Selanjutnya peneliti mewawancarai informan 2 adalah Pegawai BPBD Kabupaten Subang sebagai berikut: "Bicara tentang pengawasan dan pengontrolan petugas mungkin kami lebih memfokusakan pada kerja mereka di lapangan dan untuk mengetahui itu biasanya kami mengadakan agenda rapat per 3 bulan sekali sebagai bahan evaluasi sejauh mana program kami bejalan apakah sesuai target yang kami harapakan ataupun malah sebaliknya kepada masyarakat, baik masyarakat yang mengikuti penyuluhan maupun yang tidak ikut saat penyuluhan tersebut." (Hasil Wawancara, 15 November 2019)

Berdasarkan Hasil keterangan wawancara dengan salah satu Pegawai BPBD Kabupaten Subang mengenai responsibilitas, dapat digambarkan sama hal nya dengan apa yang dikatakan oleh Kepala Bidang Mitigasi Kab.Subang bahwa fungsi pengawasan itu dilakukan untuk meningkatkan kinerja para pegawai di lapangan mengenai sosialisasi maupun penyuluhan yang diberikan kepada masyarakat.

Hasil wawancara di atas menjelaskan bahwa kegiatan pengontrolan dan pengawasan yang Bidang Mitigasi lakukan sudah sesuai dengan SOP yang berlaku yakni per 3 bulan sekali diadankannya agenda rapat untuk mengetahui sejauh mana kerja para petugas dalam menjalankan program yang sudah di tentukan untuk mencapai tujuan organisasi.

Apabila permasalahan tersebut dikaitkan dengan teori yang dikemukakan oleh Agus Dwiyanto (1995:9), bahwa proses pengontrolan dan pengawasan pada indicator responsbilitas sudah optimal sebab Bidang Mitigasi melakukan pengontrolan degan mengadakan rapat evaluasi setiap per 3 bulan sekali untuk mengetahui sejauh mana program berjalan dan di pertanggug jawabkan oleh para petugas di lapangan. 


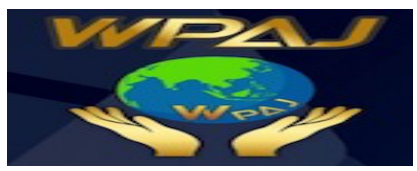

Volume 2 Issue 1, Juni 2020

http://ejournal.unsub.ac.id/index.php/publik

Akuntabilitas

Akuntabilitas publik menunjuk pada seberapa besar kebijakan dan kegiatan organisasi publik tunduk pada para pejabat politik yang dipilih oleh rakyat. Asumsinya adalah bahwa para pejabat politik tersebut dipilih oleh rakyat, sehingga dengan sendirinya akan selalu merepresentasikan kepentingan rakyat. Dalam konteks ini, konsep akuntabilitas publik dapat digunakan untuk melihat seberapa besar kebijakan dan kegiatan organisasi publik itu konsisten dengan kehendak masyarakat banyak. Kinerja organisasi publik tidak hanya bisa dilihat dari ukuran internal yang dikembangkan oleh organisasi publik atau pemerintah, seperti pencapaian target, akan tetapi kinerja sebaiknya harus dinilai dari ukuran eksternal, seperti nilai-nilai dan norma yang berlaku dalam masyarakat. Suatu kegiatan organisasi publik memiliki akuntabilitas yang tinggi kalau kegiatan itu dianggap benar da n sesuai dengan nilai dan norma yang berkembang dalam masyarakat.

Berkaitan dengan akuntabilitas lebih menekankan kepemilikan tuggal atas tindakan dan keputusan mengenai tugas yang berarti kualitas bertanggung jawab atas apa yang di lakukan dan mampu memberikan alasan sejauh mana alasan terebut memuaskan untuk setiap hal yang tejadi karenanya. Akuntabilitas sepenuhnya berorientasi pada individu dan tidak dapat di bagiakan kepada orang lain oleh karena itu menjadi bertanggung jawab berarti tidak hanya bertanggung jawab atas tugas tetapi bertanggung jawab juga untuk menjawab dan membuktikan tindakan yang sudah di lakukan. Akuntabilitas menggambarkan kewajiban setiap individu dan bukan tugas yang di tugaskan oleh orang lain atas individu setelah itu individu memutuska untuk menerima responsibilitas itu untuk kemudian di kerjakan, maka peneliti melakukan wawancara dengan informan 1 adalah Kepala Bidang Mitigasi Kabupaten Subang, beliau mengatakan : "Perihal pertanggung jawaban atas kesalahan individu maupun kelompok dari pihak kita ataupun kekeliruannya dalam melaksanakan tugas nya, saya sebagai atasannya akan menegur petugas tersebut dan meminta penjelasannya lewat hasil kerja kenapa bisa terjadi kekeliruan seperti itu serta memberikan motivasi agar semangat kembali." (Hasil Wawancara, 15 November 2019)

Berdasarkan Hasil keterangan wawancara dengan Kepala Bidang Mitigasi Kabupaten Subang mengenai akuntabilitas, dapat digambarkan bahwa pertanggungjawaban yang diberikan oleh Kepala Bidang Mitigasi Kab.Subang adalah menindak tegas pegawai yang melakukan kerja kurang optimal, tindakan itu berupa teguran yang diberikan kepada pegawai dan membuat komitmen akan kinerja yang lebih baik lagi untuk kedepanya.

Berdasarkan Hasil keterangan wawancara dengan Pegawai BPBD Kabupaten Subang mengenai akuntabilitas, dapat digambarkan bahwa pegawai jika mengalami kekliruan dalam pelaksanaan kegitan itu akan dibahas pada saat rapat rutin yang dilakukan setiap 3 bulan sekali, dapat rapat tersebut dapat dipaparkan kendala yang ada pada saat pelaksanaan kegiatan penyuluhan sehingga Kepala Bidang bisa mengambil tindakan yang tepat untuk melakukan evaluasi kedepanya.

Kemudian peneliti mewanacarai informan 3 adalah pegawai BPBD Kabupaten Subang, sebagai berikut: "Kalau soal pertanggung jawaban dari kesalahan yang dilakukan petugas kami akan melakukan pemanggilan pada petugas tersebut untuk 


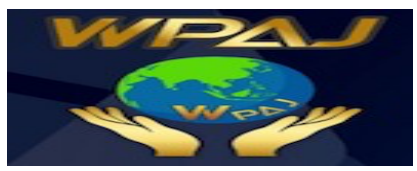

Volume 2 Issue 1, Juni 2020

http://ejournal.unsub.ac.id/index.php/publik

dimintai keterangan atas kesalahan yang di lakukan pelaporannya sendiri berupa lisan saja mungkin". (Hasil Wawancara, 17 November 2019)

Berdasarkan Hasil keterangan wawancara dengan Pegawai BPBD Kabupaten Subang lainya mengenai akuntabilitas, beliau juga menjelaskan jika terjadi kesalahan atau kekeliriuan itu akan da pemanggilan terhadap pegawai yang melakukan kesalahan, pemanggilan itu dilakukan untuk mengetahui lebih mendalam asal mula kesalahan itu bisa terjadi, sehingga bisa dicari jalan keluarnya secara bersama-sama. (Hasil Wawancara, 18 November 2019)

Hasil wawancara menjelaskan bahwa pertanggugjawaban petugas dalam indikator pertanggungjawaban bidang mitigasi terhadap petugas lapangan sudah baik sebab mereka melakukan peneguran kepada petugas yang melakukan kesalahan dan membei sanksi jika memang kesalahan yang di lakukan sangat fatal dan merugikan masyarakat. Jika permasalahan tersebut dikaitkan dengan teori Agus Dwiyanto (1995: 9) yang dikemukakan oleh ini merupakan indikator terpenting dalam akuntabilitas sudah optimal karena mereka melakukan peneguran kepada petugas yang melakukan kesalahan dan memberi sanksi kepada mereka sesuai dengan kesalahan yang mereka lakukan terlebih kesalahan tersebut sangat merugikan masyarakat.

\section{Kesimpulan}

Berdasarkan hasil uraian penelitian dan pembahasan yang telah diuraikan dapat ditarik kesimpulan bahwa : Kinerja Bidang Mitigasi Bencana Alam Di Badan Penanggulagan Bencana Daerah Kabupaten Subang belum optimal.

Hal ini terlihat dalam teori Kinerja sebagai berikut :

1. Produktivitas

Kegiatan sosialisasi dan penyuluhan juga sebagai simulasi akan cara yang harus dilakukan pada saat sebelum dan sesudah kejadian bencana. Dengan keterbatasan dan kurang memadainya sarana dan prasarana berupa alat untuk membantu masyarakat dalam memahami dan mencerna proses sosialisasi tersebut ini juga merupakan faktor yang menjadi penghambat. Konsep produktivitas bidang mitigasi dalam kegiatan penyuluhan dan sosialiasi belum berjalan secara optimal sehingga belum mencapai hasil yang diharapkan. Dapat disimpulkan bahwa dalam produktivitas kinerja bidang mitigasi untuk kegiatan sosialisasi dan penyuluhan di sini masih perlu ditingkatkan lagi dari segi sarana dan prasarana sebab sarana dan prasarana di sini berperan penting untuk simulasi dan pemahaman masyarakat dengan peragaan yang dilakukan.

2. Kualitas Pelayanan

kualitas layanan yang di berikan Bidang Mitigasi sudah sesuai untuk kegiatan sosialisasi yang di lakukan sebagai mana itu menjadi edukasi untuk masyarakat dalam pencegahan dan penanggulangan bencana alam yang terjadi di daerah rawan bencana karena Bidang Mitigasi sendiri lebih memfokuskan melakukan kegiatan penyuluhan atau sosisalisasi pada daerah rawan bencana masih belum optimal dalam hal penyampaian informasi dan cara pengaksesan informasi bagi masyarakat belum tersampaikan dengan baik ini karena terbatasnya pengetahuan masyarakat dan ketidakjelasan informasi yang mereka terima dari pihak Bidang Mitigasi. 


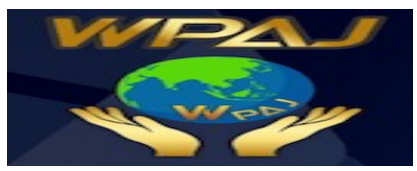

Volume 2 Issue 1, Juni 2020

http:// ejournal.unsub.ac.id/index.php/publik

3. Reponsivitas

ketanggapan Bidang Mitigasi terhadap pencegahan dan penanggulangan bencana mereka melakukan penyusunan program yang lebih mementingkan masyarakat yang tinggal di daerah rawan bencana agar mereka lebih bisa memahami cara pencegahan dan penanggulangan bencana. Maka dari itu peran Bidang Mitigasi sangat penting untuk masyarakat sebagai pemberi edukasi perihal pentingnya pencegahan dan penanggulagan bencana alam. Kegiatan ini sudah sesuai dengan pengembangan prosedur penyusunan program yang lebih memprioritaskan kepada masyarakat yang tinggal di daerah rawan bencana sehingga daya tanggap Bidang Mitigasi terhadap penyuluhan dan sosialisasi sudah optimal.

4. Responsibilitas

proses pengontrolan dan pengawasan pada indicator responsbilitas sudah optimal sebab Bidang Mitigasi melakukan pengontrolan degan mengadakan rapat evaluasi setiap per 3 bulan sekali untuk mengetahui sejauh mana program berjalan dan di pertanggug jawabkan oleh para petugas di lapangan.

5. Akuntabilitas

Pertanggungjawaban bidang mitigasi terhadap petugas lapangan sudah baik sebab mereka melakukan peneguran kepada petugas yang melakukan kesalahan dan membei sanksi jika memang kesalahan yang di lakukan sangat fatal dan merugikan masyarakat. Jadi akuntabilitas/ pertanggunngjawaban sudah optimal karena mereka melakukan peneguran kepada petugas yang melakukan kesalahan dan memberi sanksi kepada mereka sesuai dengan kesalahan yang mereka lakukan terlebih kesalahan tersebut sangat merugikan masyarakat.

\section{Referensi}

Departemen Pendidikan Nasional. 2008. Kamus Besar Bahasa Indonesia Edisi

Ke-4. Jakarta: Gramedia

Dwiyanto, Agus. 1995. Penilaian kinerja organisasi public, Jurusan Ilmu Administrasi negara. Yogyakarta: Fisippol UGM

Hasibuan, Malayu S.P. 2006. Manajemen Dasar, Pengertian dan Masalah.

Jakarta: Bumi Aksara

Irawan, Prasetya. 2006. Penelitian Kualitatif dan Kuantitatif Untuk Ilmu-ilmu

Sosial. Jakarta: FISIP UI

Nurjanah, dkk. 2013. Manajemen Bencana.Bandung: Alfabeta

Mangkunegara, A.A.Anwar Prabu 2006. Evaluasi Kinerja Sumber Daya

Manusia. Bandung: PT.Refika Aditama

Keban, Jeremias T. 2003. Indikator Kinerja Pemerintah Daerah: Pendekatan

Manajemen dan Kebijakan, Makalah Seminar Sehari. Yogyakarta:FISIPOL UGM

Mahmudi. 2013. Manajemen Kinerja Sektor Publik. Yogyakarta: UPP STIM YKPN 


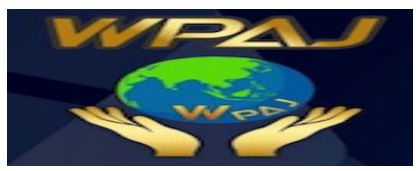

Volume 2 Issue 1, Juni 2020

http://ejournal.unsub.ac.id/index.php/publik

Mahsun, Muhammad. 2006. Pengukuran Kinerja Sektor Publik.Yogyakarta: FE UGM

Mangkunegara, Prabu Anwar .2001. Manajemen Sumber Daya Manusia

Perusahaan.Bandung: Remaja Rosdakarya

Miles, Matthew dan Michael Huberman. 2009. Analisis Data Kualitatif(Buku

Sumber Tentang Metode-metode Baru). Jakarta: UI Press

Moeheriono. 2010. Pengukuran Kinerja Berbasis Kompetensi. Bogor: Ghalia Indonesia

Moleong, Lexy J. 2007. Metode Penelitian Kualitatif. Bandung: Remaja Rosdakarya

Nurjanah,dkk. 2012. Manajemen Bencana. Bandung: ALFABETA.

Prawirosentono. 1999. Manajemen Sumber Daya Manusia, Kebijakan Kinerja

Karyawan.Yogyakarta: BPFE

Simanjuntak, Payaman J.2005. Manajemen dan Evaluasi Kinerja. Jakarta: FE UI

Sinambela, Lijan Poltak dkk. 2014. Reformasi Pelayanan Publik Teori,

Kebijakan, dan Implementasi. Jakarta: Bumi Aksara

Sobandi, Baban. 2006. Desentralisasi dan Tuntunan Penataan Kelembagaan Daerah. Bandung: Humaniora

Steers, R.M. 2003. Organization Effectiveness A Behavioral View. Jakarta: Erlangga

Sugiyono. 2008. Metode Penelitian Kuantiatif.Kualitatif dan RED. Bandung: Alfbeta

Sugiyono. 2009. Memahami Penelitian Kualitatif. Bandung: Alfabeta

Sugiyono. 2010. Metode Penelitian Admninistrasi. Bandung: Alfabeta

Surjadi. 2009. Pengembangan Kinerja Pelayanan Publik. Bandung: Refika Aditama

Taniredja, Tukiran dan Hidayati Mustafidah. 2012. Penelitian Kualitatif Sebuah

Pengantar. Bandung: Alfabeta

Wibowo. 2011. Manajemen Kinerja. Jakarta: RajaGarafindo Persada 